\title{
Is it Effective using Peer Tutoring with Realistic Mathematics Education Approach to Improve Slow Learners' Mathematics Attitudes?
}

\author{
Sumbaji Putranto, Marsigit \\ Yogyakarta State University, Jl. Colombo No.1, Karang Malang, Sleman, Yogyakarta 55281, Indonesia \\ e-mail: sumbajiputranto@gmail.com
}

\begin{abstract}
Abstrak
Penelitian ini bertujuan untuk mendeskripsikan keefektifan metode peer tutoring dengan pendekatan Pendidikan Matematika Realistik yang diterapkan di kelas inklusif untuk mengembangkan sikap matematika siswa slow learner. Penelitian ini adalah penelitian eksperimen semu dengan one group pretest-posttest design. Sampel dari penelitian ini dipilih menggunakan convenience sampling dari siswa slow learner kelas VII Sekolah Menengah Pertama yang terdiri dari 31 siswa yang tersebar ke dalam tiga kelas inklusif. Instrumen yang digunakan dalam penelitian ini adalah instrument non-tes berupa angket untuk mengukur sikap matematika siswa. Kriteria keefektifan dalam penelitian ini didasarkan pada 1) rata-rata skor angket akhir lebih tinggi dibandingkan skor angket awal, dan 2) lebih dari 75\% siswa memperoleh skor angket akhir minimal baik. Hasil penelitian menunjukkan bahwa pembelajaran menggunakan metode peer tutoring dengan pendekatan Pendidikan Matematika Realistik di kelas inklusif efektif untuk mengembangkan sikap matematika siswa slow learner.
\end{abstract}

Kata Kunci: sikap matematika, peer tutoring, Pendidikan Matematika Realistik, slow learner

\begin{abstract}
This study was aimed to describe the effectiveness of peer tutoring method with Realistic Mathematics Education approach applied in inclusive classes to improve slow learners' mathematics attitudes. Type of this research was quasi experiment with one-group pretest-posttest design. The sample was chosen by using convenience sampling from slow learners of VII Grade Junior High School which consisted of 31 students scattered into 3 inclusive classes. The instrument used in this study was a non-test instrument in form of questionnaires. The effectiveness criteria in this study was based on 1) the average score of final questionnaire was higher than the initial questionnaire score, 2) the final questionnaire score shows that more than $75 \%$ of the whole students gained the minimum "good" criteria. The result shows that applying peer tutoring learning method with Realistic Mathematics Education approach in inclusive classes was effective to improve slow learners' mathematics attitudes.
\end{abstract}

Keywords: mathematics attitude, peer tutoring, realistic mathematics education, slow learner

How to Cite: Putranto, S., \& Marsigit. (2018). Is it Effective using Peer Tutoring with Realistic Mathematics Education Approach to Improve Slow Learners' Mathematics Attitudes?. International Journal on Emerging Mathematics Education, 2(2), 179-186. http://dx.doi.org/10.12928/ijeme.v1i2.10487

\section{INTRODUCTION}

The purpose of mathematics learning is not only to improve the cognitive aspects, but also the affective aspects of students. Affective aspects are divided into four, namely beliefs, values, attitudes, and emotions (Grootenboer \& Marshman, 2016). These aspects are interrelated each other as shown in Figure 1. 


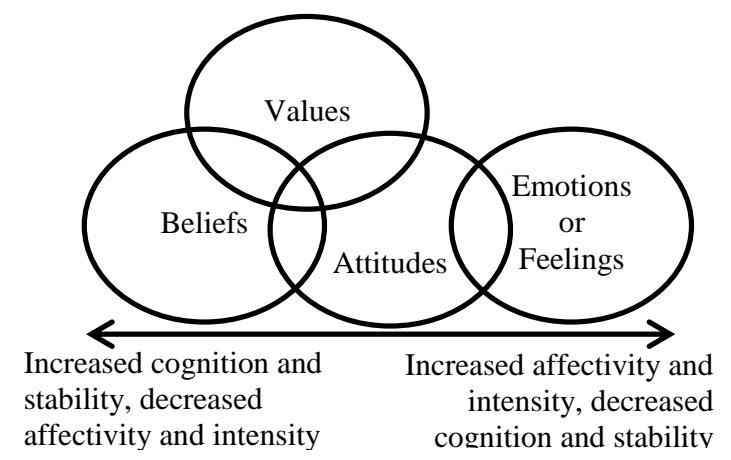

Figure 1. An illustration of affective aspects relationship

From Figure 1, it can be seen that beliefs, values and attitudes are inter-related and defined in somewhat inter-changeable ways, and also shows emotions are generally conceptualised as distinct from beliefs and values, but related to attitudes. The attitude becomes one of the important affective aspects improved for students. Fenyvesi, Koskimaa, and Lavicza (2014) states that attitudes strongly influence behavior and involve elements of knowledge and affects, and have a strong impact on education processes as well.

In the mathematics learning, the improvement of mathematics attitude becomes very important to be developed in order to assist learning implementation. This is in line with the $21^{\text {st }}$ century mathematics learning standard developed by SEAMEO (2014). Zaskis and Zaskis (2013) states that mathematics attitude relates to the students' mindset when they solve mathematics problems. Katagiri (2004) explains that students' mathematics attitudes relate to their effort when they solve a problem. The students' efforts in solving a mathematical problem include: (1) attempts to understand the problem; (2) attempts to act logically; (3) attempts to express the purpose clearly and briefly; and (4) attempts to find the better things.

This mathematics attitude becomes very important to be improved for slow learners in inclusive classes. So, these students can achieve better learning results. Slow learners can be interpreted as students who learn more slowly than their peers, but do not have mental disabilities because they can get good academic achievement although slower than students in general (Akerdi, Sadati, Moghaddam, Fereydooni, \& Moafi, 2017; Vasudevan, 2017). Based on the IQ test intelligence, the slow learners got the scores 75-90 or categorized as below average and they had low scores in almost all of the subjects (Chauchan, 2011; Dasaradhi, Rajeswari, \& Badarinath, 2016; Malik, 2009; Mohammad \& Mahmoed, 2014; Suarez, Berdut, \& Gueton, 2017).

In addition, it is necessary to develop a learning that can facilitate the process of active learning for slow learners in inclusive classes to improve slow learners' mathematics attitudes. Peer tutoring method can be chosen as one of cooperative learning methods that can be applied for learning in inclusive classes. Some terms that have the same meaning with peer tutoring are peer-assisted learning, peer-mediated instruction and interventions, peer teaching, peer education, and student team learning (Okoroma, 2013). Peer tutoring is learning that combines students with high and low achievement in a small group so students with high scores can assist other students with low scores (Mkpanang, 2016; Mastropieri \& Scruggs, 2006). Through this method students can help each other and improve their individual abilities while assist their friends. Abdurrahman and Garba (2014) and Tsuei (2014) suggest that peer tutoring can improve student learning achievement. 
Furthermore, the selection of learning approaches also need to be considered in order to maximize the potentials of slow learners. Realistic Mathematics Education approach can be applied to provide the problems concretely or real life learning experiences. It is because slow learners can get higher achievement when the information is conveyed concretely but will find learning difficulties when the information are presented abstractly (Shaw, 2010). De Lang (1987) states that the principles used in the development of learning with the Realistic Mathematics Education approach are 1) the use of real situations, 2) the existence of the process of mathematization and reflection, 3) the existence of abstraction and formalization process, and 4) matematization in application.

Some of studies related to Realistic Mathematics Education show that learning using Realistic Mathematics Education approach can improve various abilities for students (Wulandari, Dafik, \& Susanto, 2014; Hidyat \& Iksan, 2015). So this approach also has affect to improve mathematics attitudes of slow learners. Seeing the positive potential of peer tutoring learning and Realistic Mathematics Education approach in mathematics learning, this study aims to find out how the effectiveness of peer tutoring learning with Realistic Mathematics Education approach to improve mathematics attitudes of slow learners in inclusive classes.

\section{RESEARCH METHOD}

The type of this research was a quasi-experiment with one-group pre-test-posttest design. The design of this research was presented in Figure 2.

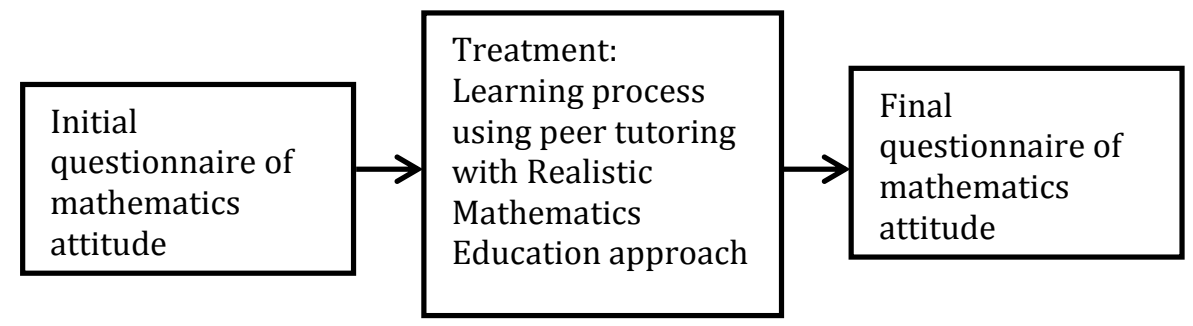

Figure 2. Research Design

The research was conducted in 3 inclusive classes consisted of 92 students. Some types of children with special needs in those classes were 1 deaf student, 3 autism students, and 31 slow learners. This research focused on the mathematics attitude achievement of slow learners in inclusive classes. Determinations of slow learners were based on the result of intelligence test and students learning outcomes. In addition, the sampling technique of this research was convenience sampling (Creswell, 2012).

The instrument used in this research was a non-test in form of questionnaire. It was compiled in form of checklist consisted of 22 questions. The statement in the first and final questionnaire had the same format but presented in different sequence. The used model was likert scale (Gable, 1986).

After compiling the instrument, to find out proof validation, the instrument was assessed by two experts. Furthermore, based on the reliability estimation using alpha Cronbach, coefficient value for the questionnaire was 0.817. Nunnally (1987) argues that coefficient of the instrument was high enough. It could be said that the questionnaire used in this research was reliable. 
After collecting the data, normality test by using one-sample kolmogrov-smirnov would be done. Then carried out the hypothesis test to show effectiveness of the used learning method by 1) examining if mean score of final questionnaire higher than initial questionnaire by using paired t-test, and 2) examining whether $75 \%$ of the whole students gained score above the minimum "good" categorized by using z test.

\section{RESULTS AND DISCUSSION}

The initial data of mathematics attitude were obtained through the questionnaire that was filled before the treatment was given. While the final data of mathematics attitude were obtained through the questionnaire that was filled after six times the lessons were completed. In Table 1, the statistical data of the initial and final questionnaire of slow learners' mathematics attitudes were presented.

Tabel 1. Data Statistic of Mathematics Attitude Questionnaire Score

\begin{tabular}{lcc}
\hline \multicolumn{1}{c}{ Data Statistic } & $\begin{array}{c}\text { Initial } \\
\text { Questionnaire }\end{array}$ & $\begin{array}{c}\text { Final } \\
\text { Questionnare }\end{array}$ \\
\hline Mean & 2,91 & 3,56 \\
Modus & 2,73 & 3,55 \\
Standard Deviation & 0,44 & 0,24 \\
The Highest Score & 3,77 & 3,82 \\
The Lowest Score & 2,00 & 2,64 \\
\hline
\end{tabular}

From Table 1, it can be observed that the average questionnaire scores of mathematics attitudes increases. This enhancement occurred in every aspect of students' mathematics attitude as shown in Table 2. In addition, out of 31 slow learners who filled the final questionnaire, 29 students categorized as "good" and 2 students had "sufficient" category.

Tabel 2. The Mean Score of Mathematics Attitude Questionnaire Score

\begin{tabular}{lcc}
\hline \multicolumn{1}{c}{ Aspects of Mathematics Attitude } & $\begin{array}{c}\text { Initial } \\
\text { Questionnaire }\end{array}$ & $\begin{array}{c}\text { Final } \\
\text { Questionnare }\end{array}$ \\
\hline Attempts to understand the problem & 2,88 & 3,69 \\
Attempts to act logically & 3,10 & 3,87 \\
Attempts to express the purpose & 2,74 & 3,37 \\
clearly and briefly & & \\
Attempts to find the better things & 2,79 & 3,20 \\
\hline
\end{tabular}

The normality test would be done before hypothesis test. Based on the Kolmogorov-Smirnov test, the initial and final questionnaire of mathematics attitudes was normally distributed. Furthermore, the hypothesis test results will be mentioned as follows.

1) $t_{\text {calculation }}=8,40>t_{\text {table }}=1,697$ then $H_{0}$ is rejected at the significant level of 0.05 . So it can be said that the average value of the final questionnaire score is higher than the value of the initial questionnaire score.

2) $z_{\text {calculation }}=2,38>z_{\text {table }}=1,645$, then $H_{0}$ is rejected at the significant level of 0.05. So it can be said that the percentage of the final questionnaire score reached the minimum category of well over $75 \%$. 
Based on the result of hypothesis test, peer tutoring learning with Realistic Mathematics Education approach is effective to improve slow learners' mathematics attitudes. Applying Realistic Mathematics Education approach in learning processes are begun by providing real situations. It aims to assist slow learners to understand the materials. The real situation presented in student's worksheet shown by using the projector or presented by teacher's demonstration. The examples of real situation provided in student's worksheet are the comparison of the number of students in the photo, brownie cake recipe for numbers comparison material. Students can perform the matematization process if they already understand the presented situations or problems. The process of students understanding the problems are realized through "let's observe" and "let's ask" activities. Students' attempt to understand the problem or the purpose clearly is the realization of their efforts to solve mathematics problems well (Katagiri, 2004). Thus, through understanding real situation activities presented at the beginning of learning process can affect mathematics attitudes of slow learners.

The next activity is the process of mathematization. This process is obtained through discussion activities in the tutoring group. Retnowati and Jaelani (2009) argues that discussion among students can help them to collect the information needed. The group learning allows students to complete each other's information. This activity allows students to be familiar with the logical steps. They will be able to determine the formal form of mathematics. In addition, they will use to trying to find out the best result from their discussion. These two things are the indicators mathematics attitudes. It can be said that mathematization process by applying discussion activities can affect students' mathematics attitudes.

Moreover, in group discussion activities students feeling excited when they try to understand and find the best was to solve the problems. Some of tutoring groups join when other groups get the better solution. It shows that students do a really good effort when they solve mathematics problems. It means that students have improved their mathematics attitude better.

After doing the discussion activity, students have a chance to present the results of their discussion in the class. Teacher gives more opportunities to slow learners to present the results of their group discussion in the class. The learners are accustomed to be able to express their opinions orally and in writing. Katagiri (2004) declares that trying to present something clearly is a part of a good attempt at solving mathematics problems. Thus, through presentation activities students can improve the better mathematics attitudes.

When the process of the results the discussion presentation proceeds, other groups have the opportunity to express their ideas if they have different opinion and solution through question and answer activities. In this activity, the teacher asks slow learners first to express their opinions or to ask questions. Through this process, learners will try to find out the better solutions. Katagiri (2004) states that student's attempt to present something clearly is part of a good attempt at solving mathematics problems. Thus, through question and answer activities students can improve the better mathematics attitudes.

Some of explanations above show that the series of activities that had done in the learning process have influences on the aspects of mathematics attitudes. It makes peer tutoring learning with Realistic Mathematics Education approach effective to be applied in inclusive classes in order to improve slow learners' mathematics attitudes. 


\section{CONCLUSION}

Mathematics attitudes of slow learners can be improved through peer tutoring learning with Realistic Mathematics Education approach. So teachers can use these ideas as one of their alternative learning methods and approaches that can be applied in inclusive classes to improve slow learners' mathematics attitudes. In this study, other students with special needs such as autism and deaf have not been maximally facilitated in this learning process. Even though there is an assistance teacher, the students are not maximal while doing the process of tutoring. Therefore, the further research needs to give more attention related to the inclusiveness in the class. So that research can find out the effectiveness of peer tutoring learning with Realistic Mathematics Education approach for other students with special needs. Moreover, the research also can observe the effectiveness of this method and approach to improve another cognitive or affective aspects of slow learners.

\section{REFERENCES}

Abdurrahman, M.S., \& Garba, I.M. (2014). Influence of laboratory activities and peer tutoring on slow-learners achievement and retention in senior secondary school trigonometry, Kebbi State Nigeria. International Journal of Advance Research, 2(12), 1-17.

Akerdi, E.M., Sadati, S.F.R., Moghaddam, T.A., Fereydooni, F., \& Moafi, M. (2017). Investigating the educational and behavioral problems of slow-learners of Neka during 2013-2014. International Academic Journal of Social Science, 4(3), 9-16.

Chauhan, M.S. (2011). Slow learners: Their psychology and educational programmes. International Journal of Multidisciplinary Research, 1(8), 279-289.

Creswell, J.W. (2012). Education research: Planning, conducting and evaluating quantitative and qualitative research ( $4^{\text {th }}$ edition). Boston, MA: Pearson.

Dasaradhi, K., Rajeswari, C.S.R., \& Badarinath, P.V.S. (2016). 30 methods to improve learning capability in slow learners. International Journal of English Language, Literature and Humanities, 6(2), 556-570.

De Lang, J. (1987). Mathematics, Insight, and Meaning. Utrecht: OW \& WO.

Fenyvesi, K., Koskimaa, R., \& Lavicza, Z. (2015). Experiential education of mathematics: Art and games for digital natives. Kasvatus ja aika, 9(1), 107-134.

Gable, R. K. (1986). Instrument Development in the Affective Domain. New York: Springer Science Business Media.

Grootenboer, P., \& Marshman, M. (2016). Mathematics, Affect and Learning, Middle School Students' Beliefs and Attitudes Mathematics Education. New York: Springer.

Hidayat, R., \& Iksan, Z. H. (2015). The effect of realistic mathematic education on students' conceptual understanding of linear progamming. Creative Education, 6(22), 2438-2445.

Katagiri, S. (2004). Mathematical Thinking and How to Teach It. Tokyo: Meijitosyo Publishers.

Malik, S. (2009). Effect of intervention training on mental abilities of slow learners. International Journal Education Science, 1(1), 61-64.

Mastropieri, M. A., \& Scruggs, T. E. (2007). The inclusive classroom: Strategies for effective instruction. New Jersey: Merrill/Prentice Hall.

IJEME, Vol. 2, No. 2, September 2018, 179-186. 
Mohammad, T.Z., \& Mahmoud, A.M. (2014). Clustering of slow learners behavior for discovery of optimal patterns of learning. International Journal of Advanced Computer Science and Applications, 5(11), 102-109.

Mkpanang, J.T. (2016). Effects of classwide and reciprocal peer tutoring strategies on students' mathematical problem-solving achievement in electricity concpets in physics. International Journal of Education, Learning and Development, 4(3), 37-44.

Nunnally, J.C. (1978). Psychometric theory (2 ${ }^{\text {nd }}$ ed.). New York, NY: McGraw-Hill.

Okoroma, F.N. (2013). The impact of peer tutoring on librarians in training at the University of Ibadan, Nigeria. Academic Journal, 8(21), 2059-2070.

SEAMEO. (2016). Working Paper for SEAMEO Basic Education Standards (SEA-BES): Common Core Regional Learning Standards in Mathematics. Penang, Malaysia: SEAMEO.

Retnowati, E., \& Jaelani. Implementasi teknik jigsaw dalam pembelajaran geometri sebagai upaya meningkatkan hasil belajar dan kemandirian belajar siswa kelas IX SMU Negeri 1 Depok Yogyakarta. Pijar MIPA, 4(1), 35-41.

Shaw, S.R. (2010). Rescuing students from the slow learner trap. Principal Leadership, $10(6), 12-16$.

Suarez, M.R.F., Berdut, I.R., \& Gueton, P.M.R. (2017). Chalange for teachers in class: how to cope with slow learners. The International Journal of Humanities \& Social Studies, 5(2), 58-62.

Tsuei, M. (2014). Mathematics synchronous peer tutoring system for students with learning disabilities. Educational Technology \& Society, 17(1), 115-127.

Vasudevan, A. (2017). Slow learners - Cause, problems, and educational programmes. International Journal of Applied Research, 3(12), 308-313.

Wulandari, A.A., Dafik, \& Susanto. (2014). Penerapan pembelajaran matematika realistik dengan whole brain teaching pada pokok bahasan teorema pythagoras untuk meningkatkan hasil belajar dan aktivitas siswa tunarungu kelas VIIIB SMPLB Sinar Harapan Probolinggo Tahun Ajaran 2014/2015. Jurnal Edukasi, 1(2), 40-46.

Zazkis, R., \& Zazkis, D. (2013). Mathematical thinking: how to develop it in the classroom. Research in Mathematics Education, 15(1), 89-95. 
